\title{
Regional Trade Agreements in the WTO System: Potential Issues and Solutions
}

\author{
Yong Shik Lee*
}

In the international trading system today, regional trade agreements, referring to reciprocal trade agreements between two or more countries providing exclusive trade preferences, govern not only the trade relations among the parties to the RTAs, but also form additional sets of trade disciplines. These agreements exist parallel to the multilateral trading system under the auspices of the World Trade Organization. The GATT/WTO rules authorize RTAs under certain conditions; thus on the surface, RTAs appear to be a legitimate part of the WTO system. However, in substance, the preferential terms of trade in RTAs are essentially in conflict with the most important principle of the WTO system, the most-favored-nation treatment. The current proliferation of RTAs thus makes exclusive RTA preferences, which are supposedly an exception to the MFN principle, a rule rather than an exception. This article examines GATT/WTO rules on RTAs, addresses the potential conflict between RTAs and the WTO system with potential solutions, and analyzes RTAs from the development perspective.

\section{Keywords}

Regional Trade Agreements, Multilateral Trading System, World Trade Organization, Developing Countries.

* Director of the Law and Development Institute and Distinguished Scholar in Residence, Emory University School of Law. A.B.(Berkeley), B.A./M.A./Ph.D. (Cantab). The author is grateful to Ms. Livia Popp, graduate student at BabesBolyai University, for research assistance. The author may be contacted at: yslee@lawanddevelopment.net / Address: Emory University School of Law, 1301 Clifton Road, Atlanta, GA 30322 USA. 


\section{Introduction}

Regional trade agreements ("RTAs") are reciprocal trade agreements between two or more countries that constitute a salient feature of the international trading system today. RTAs have been rapidly proliferated since 1990, from 27 RTAs reported to the WTO in 1990 to 612 as of April 2015. ${ }^{1}$ RTAs are essentially important in the current international trading system because the terms of RTAs govern not only the trade relations among the participating countries as intended, but also form additional sets of trade disciplines that exist parallel to the multilateral trading system prescribed by the World Trade Organization ("WTO"). The WTO Member Countries (hereinafter Members) have to deal with the legal disciplines of the WTO and those of RTAs at the same time. As every WTO signatory is a member of one or more RTAs, a majority portion of world trade, ${ }^{2}$ which is subject to the legal disciplines of the WTO, is also governed by the terms of RTAs.

On the surface, RTAs appear to be a legitimate part or sub-set of the WTO system, rather than a separate trade regime or separate set of trade disciplines because the GATT/WTO rules authorize RTAs subject to certain conditions. ${ }^{3}$ In substance, however, the preferential terms of trade (trade preference) in RTAs are inherently in conflict with the most important principle of the WTO system, the most-favorednation ("MFN") treatment. The proliferation of RTAs has indeed made trade preferences afforded by RTAs, which are supposedly an exception to the MFN principle, a rule rather than an exception. ${ }^{4}$ This causes a significant systematic issue for the multilateral trading system ("MTS") whose main purpose is to develop an

1 WTO, Regional Trade Agreements, available at https://www.wto.org/english/tratop_e/region_e/region_e.htm (last visited on July 2, 2015). Of these, 426 notifications were made under GATT Article XXIV; 39 under the Enabling Clause; and 147 under Article V of the GATS. These notifications counted goods and services separately; thus the figure corresponds to 449 physical RTAs (counting goods, services and accessions together), of which 262 are currently in force.

2 According to the OECD, RTAs cover more than half of international trade and operate alongside multilateral agreements under the WTO. See OECD, Regional Trade Agreements, available at http://www.oecd.org/tad/benefitlib/ regionaltradeagreements.htm (last visited on Sept. 27, 2015).

3 GATT art. XXIV and GATS art. V. See the official website of the WTO, available at https://www.wto.org/english/ docs_e/legal_e/legal_e.htm (last visited on July 2, 2015).

4 Renato Ruggiero, the former director-general of the WTO, warned against the proliferation of preferential trading groups under this exception, stating that: "With the proliferation of regional groupings, the exception could become the rule, and this would risk changing completely the nature of the system." See Regional initiatives should aim for a free Global Market, says Ruggiero, WTO Press ReLEASE (Apr. 24, 1996), available at https://www.wto.org/english/news_e/ pres96_e/pr046_e.htm (last visited on July 9, 2015). 
open and non-discriminatory trading system. ${ }^{5}$

The proliferation of RTAs causes a potential conflict in the application of trade rules, customs procedures, and dispute settlement processes. The potential conflict is not only with the WTO disciplines but also with the rules of other RTAs. These conflicting rules may be applying to the same trade where the countries have joined multiple RTAs with overlapping membership as illustrated by the following diagram (Figure 1).

Figure 1: RTAs and Overlapping Membership ${ }^{6}$

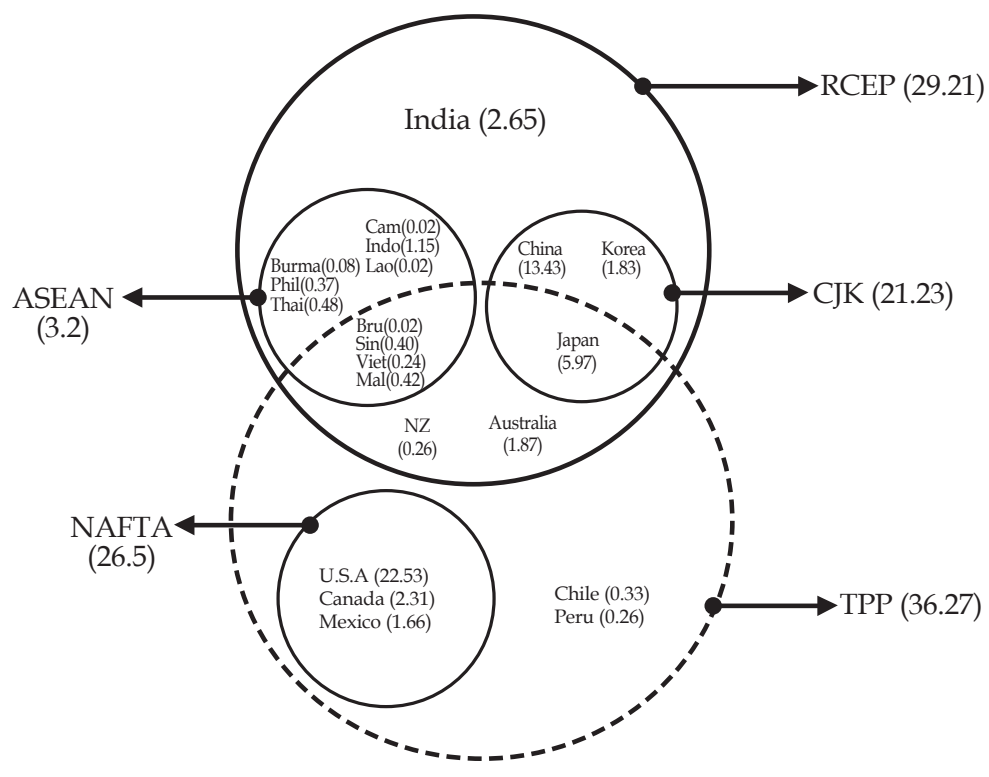

Source: Compiled by the author (GDP shares as of 2014 in the parenthesis)

RTAs, particularly those between developed countries and developing ones, may also have an effect of 'locking' the industrial structure of the participating developing

5 The preamble to the Agreement Establishing the World Trade Organization (hereinafter WTO Agreement) sets out the objectives. It aims to "contribut[e] to these objectives by entering into reciprocal and mutually advantageous arrangements directed to the substantial reduction of tariffs and other barriers to trade and to the elimination of discriminatory treatment in international trade relations...." See The WTO Agreement pmbl., available at https://www. wto.org/english/docs_e/legal_e/04-wto.pdf (last visited on July 9, 2015).

6 For details, see IMF, World Economic Output 2015, available at http://www.imf.org/external/pubs/ft/weo/2015/01/pdf/ text.pdf (last visited on Nov. 5, 2015). 
countries, thereby undermining their long-term development potential. ${ }^{7}$

Reflecting on these issues, this article will critically address the potential issues relating to RTAs in the WTO system and their corresponding solutions. This paper is composed of five parts, including a short Introduction and Conclusion. Part two will generally introduce current RTAs in the WTO legal disciplines. Part three will analyze the possible issues with those RTAs and propose possible solutions to some of the problems caused by their proliferation. Part four will discuss the question regarding RTAs and development.

\title{
II. Regional Trade Agreements in the WTO Legal Disciplines
}

\section{A. RTAs as a deviation from the MFN principle?}

The objective of RTAs is to afford trade preferences among participating countries in the form of trade liberalization, which includes the elimination of import tariffs and other non-tariff barriers. The trade preferences are exclusive to the participating countries; this 'exclusivity' is inherently inconsistent with the MFN principle of the GATT/WTO rules. Article I of GATT provides:

\begin{abstract}
With respect to customs duties and charges of any kind imposed on or in connection with importation or exportation or imposed on the international transfer of payments for imports or exports, and with respect to the method of levying such duties and charges, and with respect to all rules and formalities in connection with importation and exportation, and with respect to all matters referred to in paragraphs 2 and 4 of Article III, any advantage, favour, privilege or immunity granted by any contracting party to any product originating in or destined for any other country shall be accorded immediately and unconditionally to the like product originating in or destined for the territories of all other contracting parties. ${ }^{8}$
\end{abstract}

Article II of the General Agreement on Trade in Services ("GATS") also stipulates the MFN principle with respect to trade in services. ${ }^{9}$ The MFN principle is the essential

7 Yong Shik Lee, Foreign Direct Investment and Regional Trade Liberalization: A Viable Answer for Economic Development?, 39 J. WORLD TRADE 701-17(2005)

8 GATT art.1, $\uparrow 1$.

9 GATS art. I:1. It provides: "With respect to any measure covered by this Agreement, each Member shall accord 
element of the multilateral trade disciplines; it prevents the discriminatory trade practices which led to trade protectionism and a downward spiral of retaliations. ${ }^{10}$ Thus, the erosion of the MFN principle could potentially cause the destabilization of the world trading system again. GATT Article XXIV and GATS Article V-which authorize RTAs that afford trade preferences with respect to trade in goods and trade in services, respectively-function as exceptions to this critical principle. Both GATT Article I and GATS Article II also stipulate exceptions, including the trade preferences and the deviations from the MFN treatment listed in the Annexes. ${ }^{11}$ RTAs may also be authorized under the GATT Decision on Differential and More Favorable Treatment, Reciprocity and Fuller Participation of Developing Countries (hereinafter Enabling Clause), which waives the MFN requirement under GATT Article 1 for regional agreements entered into among developing contracting parties for the mutual reduction or elimination of tariffs." 12

The authorization of RTAs traces back to the beginning of the GATT regime after World War II. The then-existing trade preferences administered by the countries that prevailed in the war, such as the trade preference within the British Commonwealth, needed to be preserved. Subsequent trade preferences, such as those inherent in the European Economic Communities, that were negotiated by former enemies in Europe-Germany and France - also needed to be promoted in the interest of regional peace and stability. ${ }^{13}$ Beyond the political considerations, the authorization of RTAs could also be viewed and justified as an expansion of free trade areas, which would be consistent with the interest of open trade promoted by the GATT/WTO system. ${ }^{14}$ Nonetheless, the 'exclusivity' of the trade preferences which are afforded only among the countries participating in the RTAs is a point of conflict with the MFN requirement applied to all WTO Members. The remainder of this subsection examines the key provision of Article XXIV to explore this point further.

immediately and unconditionally to services and service suppliers of any other Member treatment no less favourable than that it accords to like services and service suppliers of any other country."

10 The trade protectionism in the 1930s in the aftermath of the Great Depression is considered a cause of World War II. See generally A. Crozier, The Causes of the Second World War (1997).

11 GATT art. I, ๆ 2 \& GATS art. II, ๆ 2.

12 GATT, Decision on Differential and More Favourable Treatment, Reciprocity and Fuller Participation of Developing Countries (Enabling Clause), Decision of 28 November 1979 (L/4903), ๆ 2(c), available at https://www.wto.org/ english/docs_e/legal_e/enabling_e.pdf (last visited on July 9, 2015).

13 M. Trebilcock, R. Howse \& A. Eliason, The Regulation of International Trade 54-5 \& 84-6 (2013).

14 GATT art. XIX:4. It provides: "The contracting parties recognize the desirability of increasing freedom of trade by the development, through voluntary agreements, of closer integration between the economies of the countries parties to such agreements." 


\section{B. Regulatory Components}

\section{Formation of RTAs}

GATT Article XXIV:5 authorizes the formation of RTAs in the form of free trade areas and customs unions. ${ }^{15}$ A free trade area liberalizes trade between the participating countries, but each participating country maintains its own trade policy, such as a separate tariff schedule. A customs union, such as European Union, liberalizes trade internally and also maintains a common external trade policy, including a common tariff schedule. GATS Article V:1 authorizes "an agreement liberalizing trade in services between or among the parties to such an agreement" without a distinction between a free trade area and a customs union. ${ }^{16}$ RTAs have the potential to become exclusive trade blocs as appeared in the 1930s, which provided trade preferences to the participating countries but raised trade barriers like increased tariffs to the countries outside the blocs. ${ }^{17}$ To prevent this type of trade protectionism, Article XXIV:5 subjects the authorization of RTAs to an important condition: "The duties and other regulations of commerce imposed ... shall not on the whole be higher or more restrictive than the general incidence of the duties and regulations of commerce ... prior to the formation.",18

Accordingly, the RTAs created under the auspices of GATT/WTO rules, on the surface, appear to be compatible with the objective of open trade as they do not raise trade barriers vis-à-vis countries not participating in the RTAs. However, the inherent exclusivity of trade preferences afforded by RTAs may adversely affect the trade of non-member countries. E.g., suppose country A and country C are both subject to a tariff rate of 7 percent ad valorem on the export of its automobiles to country B under the MFN requirement. Suppose also that country B and country C form an RTA liberalizing trade between them, but country A does not participate in the RTA. After the formation of the RTA, which eliminates the seven (7) percent tariff on the export of automobiles between countries B and C, the automobile exporters of country A will be disadvantaged in its automobile exports to country B;

15 GATT art. XIX:5. It provides: "The provisions of this Agreement shall not prevent, as between the territories of contracting parties, the formation of a customs union or of a free-trade area or the adoption of an interim agreement necessary for the formation of a customs union or of a free-trade area."

16 This distinction is absent because trade in service does not involve tariffs as imposed on imported goods; thus this distinction is not applicable. See also GATS art. V:1. It provides: "This Agreement shall not prevent any of its Members from being a party to or entering into an agreement liberalizing trade in services between or among the parties to such an agreement..."

17 Supra note 10.

18 GATT art. XIX, ๆ5. 
its exports of automobiles are still subject to the 7 percent tariff rate while no tariffs are applied to the automobiles from country $\mathrm{C}$ as a result of the RTA.

The disadvantage to the non-members would be greater where RTAs also reduce non-tariff barriers ("NTBs") for the benefit of RTA members. The importance of NTBs, such as technical barriers to trade like product safety and sanitary requirements, has increased as tariffs have been lowered across the board through multilateral trade negotiations (rounds). ${ }^{19}$ RTAs may include terms to facilitate mutual cooperation in the area of the technical standards and product safety requirements for the purpose of reducing NTBs. ${ }^{20}$ Some RTAs, such as the CanadaChile Free Trade Agreement, also abolish trade remedy measures, including antidumping measures, vis-à-vis trade of the other members. These preferences will substantially benefit the exporters of the member countries in the exclusion of the non-member country exporters. The reduction or removal of barriers to trade in services can also benefit the service providers of the member countries and disadvantage those of non-members substantially. Thus, RTAs essentially set a preferred trade regime for the benefit of the member countries in the exclusion of the non-members, and this differential treatment contravenes the MFN principle set out in the WTO regime.

\section{2. "Substantially all trade"}

There is a regulatory threshold for the approval of RTAs: for trade in goods, "substantially all trade" between RTA members must be liberalized (i.e. elimination of duties and other restrictive regulations of commerce) ${ }_{i}^{21}$ and for trade in services, there must be "substantial sectoral coverage," and "substantially all discrimination" must be absent or eliminated in the covered sectors. ${ }^{22}$ It should be noted that neither GATT Article XXIV nor GATS Article V requires complete trade liberalization as a prerequisite for the approval of an RTA. In Turkey - Restrictions on Imports of Textile and Clothing Products (hereinafter, Turkey - Textiles), ${ }^{23}$ the Appellate Body noted

19 There were eight rounds during the GATT era (1947-1994). During the GATT rounds, tariffs were reduced by an average of $35 \%$ at each round. As a result, the tariff rates of non-primary products of industrial countries fell to a mere 3.9\% after the Uruguay Round in 1994. See J. Jackson, The World Trading System 74 (1997).

20 E.g., Article 9 of the Free Trade Agreement between the United States of America and the Republic of Korea (US Korea FTA) mandates such cooperation. See US-Korea FTA Text, available at https://ustr.gov/trade-agreements/freetrade-agreements/korus-fta/final-text (last visited on July 2, 2015).

21 GATT art. XXIV, ๆ 8.

22 GATS art. I, 11 .

23 Turkey - Textiles, Report of the Appellate Body, WT/DS34/AB/R (October 22, 1999), available at https://docs.wto. org/dol2fe/Pages/FE_Search/FE_S_S006.aspx?Query=(@Symbol=\%20wt/ds34/ab/r*\%20not\%20rw*)\&Language=E NGLISH\&Context=FomerScriptedSearch\&languageUIChanged=true\# (last visited on July 9, 2015) 
that neither the GATT CONTRACTING PARTIES nor the WTO Members had ever reached an agreement on the interpretation of the term 'substantially' in GATT Article XXIV. ${ }^{24}$ The Appellate Body did not consider "substantially all the trade" to be the same as "all the trade," but thought it considerably more than merely some of the trade. ${ }^{25}$ Thus, it is impossible to assign numerical guidelines, such as a percentage of trade in terms of quantity; some discretion is granted to the members negotiating RTAs as to the extent of trade liberalization.

The Appellate Body, however, noted that the term "substantially all trade" has both "qualitative and quantitative components." 26 This implies that RTAs completely excluding a sector, such as agriculture, may not meet this requirement even if the quantity portion of trade in the excluded section may only be small. Some RTAs did exclude agricultural sector all together, ${ }^{27}$ but no examination report by the Committee on Regional Trade Agreements has been adopted for lack of consensus. ${ }^{28}$ According to the Understanding on the Interpretation of Article XXIV, RTAs between developing countries approved under the Enabling Clause are not asked to meet the requirement, so that partial trade liberalization would be possible under this scheme. ${ }^{29}$

\section{3. "Shall not be on the whole higher or more restrictive than before"}

GATT Article XXIV attempts to prevent the creation of exclusive trade blocs ${ }^{30}$ by requiring that a free trade area or a customs union does not raise trade barriers to the non-member countries. Thus it provides, "the duties and other regulations of commerce imposed ... shall not on the whole be higher or more restrictive than the general incidence of the duties and regulations of commerce ... prior to the formation." ${ }^{31}$ Article XXIV itself does not clarify what constitutes "higher or more restrictive" duties and other regulations of commerce. The Understanding on Interpretations of Article XXIV of the GATT 1995 provides that, in the case of tariffs, the weighted average rate

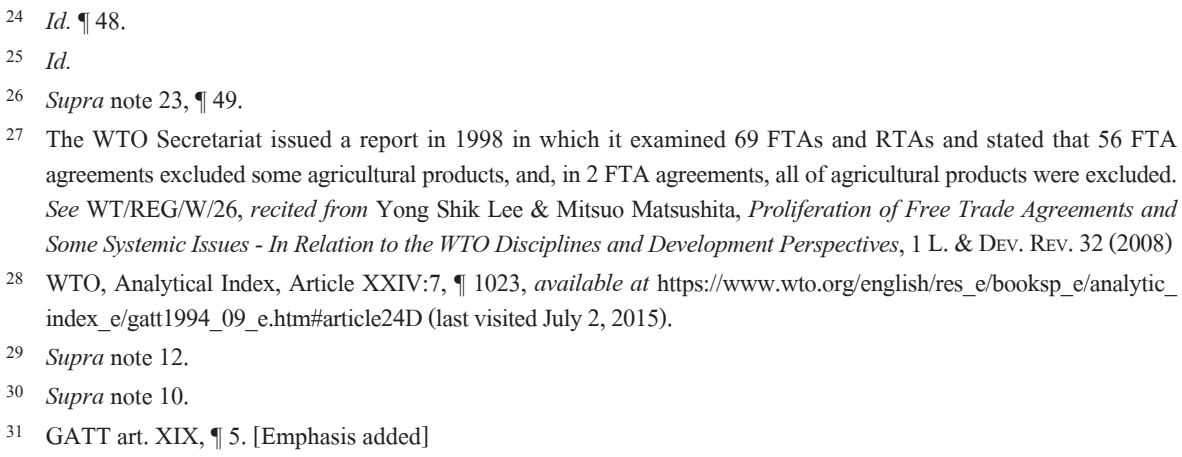
agreements excluded some agricultural products, and, in 2 FTA agreements, all of agricultural products were excluded. See WT/REG/W/26, recited from Yong Shik Lee \& Mitsuo Matsushita, Proliferation of Free Trade Agreements and Some Systemic Issues - In Relation to the WTO Disciplines and Development Perspectives, 1 L. \& Dev. Rev. 32 (2008)

28 WTO, Analytical Index, Article XXIV:7, 1 1023, available at https://www.wto.org/english/res_e/booksp_e/analytic_ index_e/gatt1994_09_e.htm\#article24D (last visited July 2, 2015).

29 Supra note 12.

30 Supra note 10.

31 GATT art. XIX, ๆ 5. [Emphasis added] 
should be used to determine restrictiveness for the formation of a customs union. ${ }^{32}$ With respect to "other regulations of commerce," the quantification and aggregation of regulations of commerce other than tariffs can be difficult, and individual measures and regulations will have to be examined. ${ }^{33}$ According to Turkey-Textiles, an economic test should be performed to assess "trade restrictiveness." 34

There is controversy as to whether rules of origin should be considered "other regulations of commerce" as trade restrictions. ${ }^{35}$ In the Working Party that examined the compatibility of the NAFTA with GATT rules, the US argued that "rules of origin are not trade restrictions as tariffs and quantitative restrictions are." According to this viewpoint, rules of origin are, unlike tariffs and quantitative restrictions, merely a test to determine the product that benefits from the preferential treatment of a FTA, but it is not a trade restriction. Another view is that rules of origin may operate as a de facto trade restriction even if they are not a trade restriction per se. ${ }^{37}$ In the Uruguay Round, negotiators addressed the issue of whether or not rules of origin were 'other restrictions,' but never reached an agreement. ${ }^{38}$

\section{Proliferation of RTAs: Issues and Solutions}

\section{A. Derogation from the MFN Principle and Exclusive Trade Preferences}

The fundamental problem caused by the proliferation of RTAs is the widespread derogation of the MFN principle stipulated by the GATT/WTO disciplines. Since international trade is subject to the disciplines of both the WTO and RTAs, the MFN tariff rates and other trade conditions agreed to at the WTO negotiations are not really the conditions of trade applicable to all of the WTO membership on a MFN basis.

\footnotetext{
32 WTO, Understanding on Interpretations of Article XXIV of the GATT 1995, ๆ 2, available at https://www.wto. org/english/res_e/booksp_e/analytic_index_e/gatt1994_09_e.htm (last visited on July 14, 2015).

33 Supra note $23, \uparrow 54$.

$34 \quad I d . \rrbracket 55$.

35 Supra note 27, at 33-4.

36 See WT/REG/M2 (Feb. 21, 1997), at 10, available at https://search.wto.org/search?q=cache:xZS_Ew-HX1sJ:www. wto.org/english/tratop_e/region_e/wtregw26_e.doc+WT\%2FREG\%2FW\%2F26\&access=p\&output=xml_no_ $\mathrm{dtd} \& \mathrm{ie}=\mathrm{ISO}-8859 \& \mathrm{client}=\mathrm{english}$ _frontend\&site=English_website\&proxystylesheet=english_frontend\&oe=UTF- 8 (last visited on July 9, 2015).

37 Supra note 27, at 34.

38 WTO, Background Note by the Secretariat, Systemic Issues Relating to “Other Regulations of Commerce," WT/REG/ W/17 (Oct. 31, 1997), recited from Yong Shik Lee et al., LaW and Development Perspective on International Trade LAW 258 (2011).
} 
Instead, these conditions merely constitute a baseline above which discriminatory trade preferences are prevalent. Although this new 'discrimination' created by RTAs may be less damaging than that caused by the trade blocs in the 1930s in the sense that the former does not 'raise' trade barriers to non-member countries, ${ }^{39}$ it still causes significant adverse trade effects, as shown above, on the trade of non-member countries. Thus, the proliferation of RTAs has fundamentally changed the world trading system, creating one system administered by the WTO on a multilateral basis and another by RTAs on a preferential basis. Both are inherently incompatible notwithstanding GATT/WTO provisions that authorize RTAs.

The advent of RTAs has led to a fragmentation of trade disciplines which will be accelerated with the further increase of RTAs. RTAs today not only eliminate tariffs and non-tariff barriers, but also set forth trade disciplines applicable to the members, such as the establishment of separate dispute settlement mechanisms, separate rules of origin, separate rules for intellectual property rights ("IPRs") and international investment, and adjustments of trade remedies. Thus, the proliferation of RTAs adds complexity and confusion to the international trading system which runs counter to the objective of creating the multilateral trading system represented by the WTO. ${ }^{40}$ Trading parties either have to accept this added complexity - flowing from a growing number of RTAs as well as the adverse consequences caused by the fragmentation of trade disciplines - or consider a fundamental reform which will address this issue.

A possible solution would be a 'sunset policy' on RTAs limiting the duration of RTA preferences to a pre-set period. ${ }^{41}$ Presently, GATT/WTO rules do not limit the life of an RTA or of the trade preferences that it offers, so both are perpetual unless the participants terminate the agreement under its terms. Thus, the deviation from the MFN principle and the regulatory fragmentation caused by the proliferation of RTAs will remain on a permanent basis unless RTA preferences are limited to a certain time period after which the preferences shall be extended to the entire WTO membership on an MFN basis. However, RTA members are unlikely to unilaterally adopt this change; trade preferences in RTAs are reciprocal in nature, so RTA members would naturally be reluctant to extend the trade preferences to non-RTA members which did not negotiate for the preference. However, this reluctance might change if they see that extending trade preference to non-members would be more

39 GATT art. XXIV, ๆ 5. [Emphasis added]

40 Supra note 5.

41 Yong Shik Lee, Reconciling RTAs with the WTO Multilateral Trading System: Case for a New Sunset Requirement on RTAs and Development Facilitation, 45 J. WorLd TRADE 625-47 (2011). 
beneficial to RTA members to adopt this change. ${ }^{42}$

The proposed extension can be achieved by collective action. At any point in time, there will be more RTAs that an RTA member has not joined than those it has. So if trade preferences in all RTAs are extended to the entire WTO membership, then the member will receive more trade preferences than those it has to extend to other non-member countries. ${ }^{43}$ Table 1 illustrates the point: an RTA member or a 'group' may stand to lose if it has to extend trade preference unilaterally, but it stands to gain, along with every other RTA member, if trade preferences in all RTAs are extended to the entire membership by cooperation. ${ }^{44}$

Table 1. Extension of Trade Preferences by RTA Group ${ }^{45}$

\begin{tabular}{|l|l|l|}
\hline & \multicolumn{1}{|c|}{$\begin{array}{c}\text { The other RTA groups } \\
\text { extend trade preferences. }\end{array}$} & $\begin{array}{l}\text { The other RTA groups do } \\
\text { not extend trade preferences. }\end{array}$ \\
\hline $\begin{array}{l}\text { RTA Group A extends } \\
\text { trade preferences }\end{array}$ & $\begin{array}{l}\text { Outcome A: Both RTA } \\
\text { Group A and the other } \\
\text { RTA groups win }\end{array}$ & $\begin{array}{l}\text { Outcome B: RTA Group A } \\
\text { loses and the other RTA } \\
\text { groups win }\end{array}$ \\
\hline $\begin{array}{l}\text { RTA Group A does } \\
\text { not extend trade } \\
\text { preferences }\end{array}$ & $\begin{array}{l}\text { Outcome C: RTA Group } \\
\text { A wins and the other } \\
\text { RTA groups lose }\end{array}$ & $\begin{array}{l}\text { Outcome D: Neither RTA } \\
\text { Group or the other RTA } \\
\text { groups win or lose. }\end{array}$ \\
\hline
\end{tabular}

Outcome D represents the current state: no RTA requires the extension of trade preferences to non-member countries, so neither members nor non-members win or lose. Collective action or cooperation will lead to Outcome A in which both RTA members and non-members win. A feasible way to secure this collective action would be to revise GATT/WTO rules to limit the life of exclusive RTA preferences and to require the extension of trade preferences to all WTO Members after a certain period of time. ${ }^{46}$ This extension requirement would also promote trade liberalization across the board. Since all WTO Members are members of one or more FTA(s), this extension might liberalize trade on a global basis. However, consideration should be given to waiving the extension requirement for developing countries to meet their development interest.

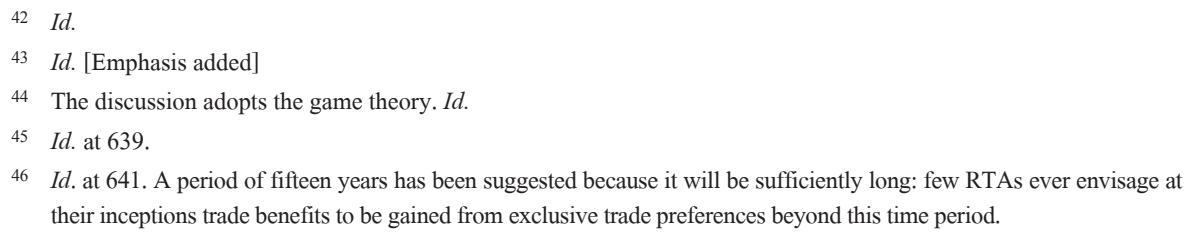
their inceptions trade benefits to be gained from exclusive trade preferences beyond this time period. 


\section{B. Fragmentation of Trade Disciplines}

Efforts should also be made to analyze relevant information about hundreds of RTAs currently in force ${ }^{47}$ so that potential conflicts and inconsistences - both between those RTAs and WTO disciplines and among the RTAs themselves - are identified and solutions are sought. RTAs notably have different regulatory approaches that may also have a considerable effect on trade. E.g., RTAs promoted by the US require substantial regulatory adjustment ${ }^{48}$ including strong protection for IPRs beyond the level of protection required under the TRIPS Agreement, promotion and protection of investment, and a high level of trade liberalization across the board including agriculture. On the other hand, China's RTAs focus more on the traditional aspects of FTAs such as lowering tariffs on trade in goods, less regulatory intervention, and more accommodation for 'sensitive areas' which are vulnerable to competition from imports and call for protection. ${ }^{49}$ Those countries that simultaneously join RTAs promoted by the US and Chin ${ }^{50}$ would have to deal with dissimilar terms imposed by these different RTAs vis-à-vis trade among them. This might cause confusion and destabilize trade practice.

Then, how should these issues with multiple RTAs be addressed? Where the level of trade preferences, such as preferential tariff rates, is different among the RTAs applicable to the trade between identical parties, an RTA member may invoke the terms of the Agreement that affords the strongest trade preference. It would be feasible because RTAs typically include a provision that requires a member to provide the MFN treatment if it offers different levels of preferences to other countries. ${ }^{51}$ The issue is more complicated if the terms of an RTA concern regulatory treatment such as IPR protection. Where one of the applicable RTAs requires a higher level of IPR protection than the others, the common members of these RTAs would probably have to decide which RTA terms should prevail with respect to trade among them.

47 Supra note 1. There is a reporting requirement, and the Committee on Regional Trade Agreements collects relevant information about RTAs.

48 For a review of US FTAs, see Yong Shik Lee, The Beginning of Economic Integration between East Asia and North America? - Forming the Third Largest Free Trade Area between the United States and the Republic of Korea, $41 \mathrm{~J}$. World Trade 1091-123(2007).

49 For details on China FTAs, see Yong Shik Lee \& Kwangkug Kim, Tripartite Free Trade Agreement among China, Korea, and Japan: A Step Towards Economic Integration in Northeast Asia?, in Regional Cooperation and Free Trade Agreements in Asia 138 (Jiaxiang Hu \& M. Vanhullebusch eds., 2014).

50 Several countries, including Brunei, Vietnam, Singapore, Malaysia, Japan, New Zealand, and Australia, are participating in the negotiations for both the Regional Comprehensive Economic Partnership ("RCEP"), driven by China, and the Trans Pacific Partnership ("TPP"), driven by the US.

51 See, e.g., US-Korea FTA, art. 1.2, ๆ 2, available at https://ustr.gov/trade-agreements/free-trade-agreements/korus$\mathrm{fta}$ /final-text (last visited on July 9, 2015). 
Arguably, a member that wants stronger protection would be able to invoke the terms of the RTA that affords it, provided that both RTAs are valid and applicable. A question remains as to whether the different terms in this type of circumstance would present a conflict, in which case an RTA later in time might prevail. ${ }^{52}$

The multitude of dispute settlement procedures is also an issue. One of the key functions of the WTO is to adjudicate trade disputes through its dispute settlement procedure. ${ }^{53}$ However, RTAs have created separate dispute settlement procedures to resolve disputes arising from the application of RTAs. ${ }^{54}$ If the subject matter of a dispute overlaps GATT/WTO disciplines and an RTA, a question of jurisdiction will arise. $^{55}$ Although some RTAs stipulate which procedure prevails, ${ }^{56}$ a member may have recourse to both the WTO dispute settlement procedure and another set up by the terms of an RTA. The breach in question may also invoke multiple RTAs, each of which may have a separate dispute settlement procedure. Members may disagree as to which has jurisdiction such that it would be possible for a claimant to file a complaint through one dispute settlement procedure, such as that of the WTO, ${ }^{57}$ and another dispute settlement body, such as that of an RTA. If both were to accept and proceed with the complaint, then there will be confusion as to which should prevail. It is therefore necessary to determine a guideline for an appropriate dispute settlement procedure in these types of cases. However, even after an appropriate

52 The Vienna Convention on the Law of Treaties ("VCLT") art. 59, ๆ 1. It provides, "A treaty shall be considered as terminated if all the parties to it conclude a later treaty relating to the same subject-matter and: (a) It appears from the later treaty or is otherwise established that the parties intended that the matter should be governed by that treaty; or (b) The provisions of the later treaty are so far incompatible with those of the earlier one that the two treaties are not capable of being applied at the same time."

53 Agreement Establishing the World Trade Organization art. III, ๆ 3. The WTO Understanding on Rules and Procedures Governing the Settlement of Dispute (Dispute Settlement Understanding) governs the dispute settlement procedure in the WTO.

54 There are three categories of dispute settlement procedures in RTAs. The first category is the NAFTA type in which a dispute settlement panel is composed on an ad hoc basis when a dispute arises and each party can bring a claim against the other. RTAs adopting this type of dispute settlement procedures include the Korea-Singapore Agreement, the Australia-Singapore Agreement and the Thai-New Zealand Agreement. The second category involves systems whereby a dispute is referred to a commission or council composed of representatives of the parties to the RTA and the council or commission renders decisions and issues recommendations. EU adopts this type of dispute settlement procedure. The third category is a hybrid of the above two types, adopted by many RTAs including the ASEAN and the Andean Community, in which a dispute is referred to a council or commission as in the second category in principle but the parties can choose to compose a panel as in the first category when the dispute is not resolved through the procedures in the second category. See supra note 27 , at 46-7.

55 For general jurisdictional issues, see Jaemin Lee, A Clash between IT Giants and the Changing Face of International Law: The Samsung vs. Apple Litigation and Its Jurisdictional Implications, 5 J. EAST AsIA \& INT'L L. 117-42 (2012).

56 Some RTAs give priority to procedures provided in the RTA (NAFTA), while others give priority to WTO dispute settlement procedure (EC-Chile Agreement) or give choice to claimants. See supra note 27, at 47.

57 Supra note 53. 
dispute settlement procedure is adopted through the proposed guideline, there is a possibility for inconsistent interpretations of relevant rules by multiple dispute settlement bodies.

Consideration should be given to creating a WTO-mandated procedure by which a party to an RTA dispute settlement process may refer a dispute to the Appellate Body, provided that: (1) the parties are also WTO Members; (2) the dispute concerns the application of GATT/WTO rules (as well as those of the RTA); and (3) the complaining party believes that the decision by the RTA dispute settlement body contravenes a previous decision adopted by the WTO Dispute Settlement Body. The Appellate Body, after review, may recommend adjustment of rulings if it finds inconsistency. This procedure may reduce the possibility of inconsistent rule interpretations between the Appellate Body and the RTA dispute settlement bodies. In addition, coordination should be made among the WTO secretariat and secretariats of RTAs to seek consistent application and interpretation of GATT/WTO rules.

\section{Weakening of the Multilateral Trading System}

The WTO system, which succeeded the GATT regime that contributed to the substantial increase in trade for five decades, ${ }^{58}$ seems to be at a deadlock, at least in two of its key functions: providing a forum for trade negotiations and setting trade rules. The first trade negotiation round of the WTO, the Doha Round, is well overdue and still not completed as of 2015, 13 years after its launch in $2001 .^{59}$ The failure to conclude the Doha Round has been partly due to major trading nations' focus on RTAs. While the difference in positions among Members slowed down the negotiation process and caused deadlocks, the diversion of limited manpower and resources available for trade negotiations from the Doha Round to a number of RTAs by major trading nations certainly did not help with the process. ${ }^{60}$

One may consider that the WTO, with its membership of 161 countries, each with an equal vote in proceedings, has reached a point where the vast divergence in the interests and priorities among Members would make any trade 'round' difficult and that RTAs would probably be the only feasible means to develop trade relations

58 International trade expanded by sixty-nine times between 1950 and 1994 under the GATT regime. See WTO statistics database, available at $\mathrm{http}$ ://stat.wto.org/StatisticalProgram/WSDBStatProgramSeries.aspx?Language=E (last visited on July 9, 2015).

59 WTO, Doha Round, available at https://www.wto.org/english/tratop_e/dda_e/dda_e.htm (last visited on July 9, 2015).

60 Since 2001, the US has been engaged in the negotiations of 12 RTAs, EU in 31 RTAs, and Canada, Japan, and South Korea in 14, 17, and 14 RTAs, respectively. See supra note 1. 
among a smaller group of nations sharing a set of common interests and priorities. From this perspective, the proliferation of RTAs may not be a harmful distraction from the multilateral trading system but a natural development. However, RTAs cannot replace the multilateral trading system. ${ }^{61}$ Despite the proliferation of RTAs and even the emergence of mega RTAs, such as EU, NAFTA, MERCOSUR, ASEAN, and TPP, RTAs could not replace the current WTO which comprehensively accommodates the divergent interests and priorities of trading nations as a whole. As such, the role of the WTO, as the only global trading system that ensures a level of open and fair trade, is still intact and needs to be protected.

This means that efforts should be made to deter further diversion of limited manpower and resources available for trade negotiations from the Doha Round, and then to bring a successful conclusion to the Round at the earliest possibility, even if it might necessitate an adjustment of goals to an achievable level. ${ }^{62}$ Confidence in the WTO needs to be restored by the successful conclusion of the Doha Round. The proposed sunset policy on RTAs would help bring Members' focus back on the agendas of the multilateral trading system. As three-quarters of the WTO membership is now comprised of developing countries, efforts to support the economic development of developing countries at an institutional level - efforts such as promotion of more pro-development governance and pro-development trade disciplines $^{63}$ - would help increase developing country participation in the WTO, participation essential to preventing the weakening of the WTO and to revitalizing the multilateral trading system.

\section{RTAs and the Development}

The vast majority of RTAs involve developing countries. ${ }^{64}$ Of these, the majority are formed under GATT Article XXIV and GATS Article V, requiring the liberalization of "substantially all trade," while a fewer number of RTAs are constituted under the

\footnotetext{
61 Director-General Roberto Azevêdo noted that bilateral and regional trade agreements have been 'growing rapidly,' but stressed that "there are many big issues which can only be tackled in an efficient manner in the multilateral context through the WTO." See Regional initiatives cannot substitute for the multilateral trading system-Azevêdo, WTO NEws, Mar. 24, 2015, available at https://www.wto.org/english/news_e/spra_e/spra50_e.htm (last visited on July 9, 2015).

62 For the negotiation agenda of the Doha Round, see supra note 59.

63 For details, see Yong Shik Lee, Reclaiming Development in the World Trading System (2009).

64 Supra note 1.
} 
Enabling Clause, which does not have this requirement. ${ }^{65}$ Since developing countries form the majority of the WTO membership and of RTA members, ${ }^{66}$ it is appropriate to discuss development interests in RTAs. The recent RTA drive accelerated by developing countries is motivated by the goal of increasing developing countries' access to export markets, while the progress of the Doha Round is stagnant. However, it is not clear whether RTAs, as they stand now, would necessarily benefit developing countries and meet their development goals. This section examines RTAs from the development perspective.

Trade measures, adopted as an infant industry promotion policy, will inevitably cause some welfare loss. The implementation of RTAs, which liberalize trade, prevents this welfare loss because RTAs eliminate trade barriers that cause such loss; thus regional trade liberalization by these RTAs is considered to promote development for the participating developing countries. ${ }^{67}$ According to the classical trade theories, the elimination of trade barriers would allow specialization in the production of products in which a country has a relative advantage, which would eventually improve economic efficiency. This rationale presents the case for promoting free trade for economic development. Nonetheless, a conclusion has already been drawn from historical study that this specialization alone did not bring about economic development, and virtually all developed countries today applied industrial promotion policies to establish some manufacturing basis with the extensive use of subsidies and trade protections. ${ }^{68}$ A study also concluded that developing economies tend to diversify, rather than concentrate, production patterns in a large cross section, suggesting that the driving force of economic development cannot be the forces of comparative advantage. ${ }^{69}$

Free trade between developing and developed countries may actually hamper the facilitation of manufacturing industries in developing countries since the elimination of trade barriers by the terms of the applicable RTA will remove the ability of developing countries to offer trade protection for their infant industries. As a result, RTAs may lock the current industrial structure of developing countries. Suppose that Korea and Chile have entered into an RTA which eliminates trade barriers on all export products, including automobiles in which Korea has

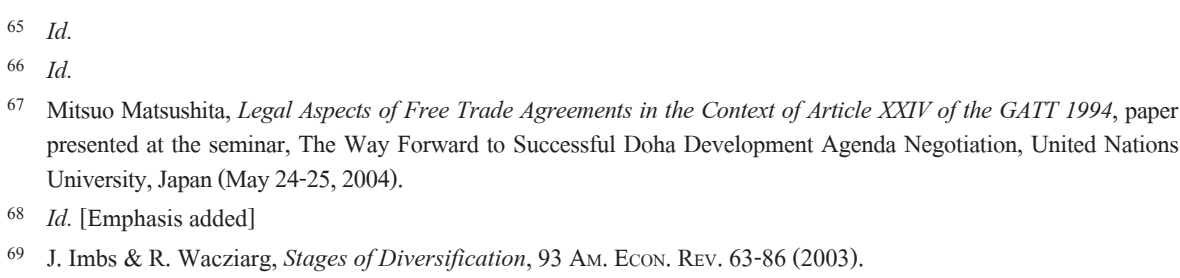
presented at the seminar, The Way Forward to Successful Doha Development Agenda Negotiation, United Nations University, Japan (May 24-25, 2004).

68 Id. [Emphasis added]

69 J. Imbs \& R. Wacziarg, Stages of Diversification, 93 Am. Econ. Rev. 63-86 (2003). 
an advantage in production and grapes in which Chile has an advantage. By eliminating trade barriers, including tariffs, Chile may have secured a larger market for its grapes, but developing an automobile industry, which is potentially more beneficial for their economic development, would become much more difficult due to the increased automobile imports from Korea. Note that Korea previously protected her domestic automobile market against imports until she achieved a level of competitiveness in its automobile industry. While the effectiveness theory of infant industry has been debated for decades, history shows that all the developed countries today protected their own industries during the periods of their economic development, ${ }^{70}$ and the GATT/WTO disciplines authorize the promotion of infant industry for economic development. ${ }^{71}$

A possible remedy to restore the ability of developing countries to adopt traderelated development policy measures would be to allow developing countries to withdraw from their RTA commitments, notwithstanding the RTA provisions, when it is deemed necessary for them to use trade measures for the purpose of promoting economic development. GATT Article XVIII also authorizes developing countries to deviate from its GATT/WTO commitments under certain conditions to promote domestic industries for the purpose of economic development. An RTA could include such a provision, but the GATT/WTO disciplines could also stipulate it as a right of a developing country member that cannot be varied by the terms of an RTA. An example of this type of regulation is Article 11 of the SA which invalidates grayarea measures $^{72}$ regardless of an agreement otherwise reached by the Members.

Another difficulty with RTAs is that developing countries are often under significant pressure to join the RTAs driven by developed countries for the fear of losing their export markets in the developed countries to competing countries. Their negotiation position against developed countries will thus be substantially weaker in negotiating RTAs than in the multilateral negotiation rounds where a greater number of developing countries can stand together to promote their common interests. Developed countries may have found it easier to negotiate with developing countries outside the multilateral framework, concluding RTAs with a smaller group of developing countries on their own terms. ${ }^{73}$ However, this ease is not a positive economic feature for developing countries, which have become a key agenda for the

\footnotetext{
70 Ha Joon Chang, Kicking Away the Ladder: Development Strategy in Historical Perspective (2002).

71 GATT art. XVIII.

72 Gray area measures include any voluntary export restraints and orderly marketing arrangements which are sought to control the quantity of imports. See SA art. 11, $\uparrow 2$.

73 Supra note 1.
} 
multilateral trading system. ${ }^{74}$

As for RTAs, the gains for developing countries, such as securing export markets on more favorable terms, should be preserved, while the barriers to economic development, such as undermining the long-term development potential by locking the current industrial structure for developing countries, should be removed. In the proposed sunset policy on RTAs, consideration should finally be given to waiving the requirement to extend trade preferences to all other WTO Members for developing countries until they have attained developed-economy status. ${ }^{75}$ As discussed, partial trade liberalization is authorized for RTAs concluded among developing countries under the Enabling Clause. This preferential treatment, however, should also be extended to RTAs concluded between developed countries and developing countries. As a consequence, the latter would be able to enter into RTAs with developed countries without having to bear the burden of full trade liberalization when they are not ready to do so. ${ }^{76}$

Comprehensive investigation should be conducted as to how hundreds of RTAs have affected the economic development of developing countries with references to their abilities to adopt trade-related development policies, terms of trade, access to export markets, and technology and capital transfers. If RTAs have caused negative impacts on them or some positive outcomes but at substantial social and political costs, such as a substantial loss of employment in the vulnerable domestic industry adversely affected by the RTA, then ways should be sought to reduce the problems. The extent of gains and losses from RTAs could be different according to the types of developing countries. Smaller developing countries tend to have weaker leverage vis-à-vis developed countries and larger developing countries in RTA relationships. Also, particular attention should be given to small and vulnerable developing countries whose economic and trade interests can easily be affected by external influence, such as RTA arrangements.

74 The primary objective of the latest Doha Round, dubbed the 'Development Round,' is to promote development interests in the WTO, as reflected in the Doha Development Agenda ("DDA"). However, its progress has been sluggish as discussed earlier. See supra note 59.

75 The developing country status is self-declared in the WTO, and there is no official guideline to determine a developed country status. Some other criteria, such as the OECD membership and the country income classification set by the World Bank, may be referenced to determine a developed country status. For the latter, see IBRD, Update Income Classification, available at http://data.worldbank.org/news/2015-country-classifications (last visited on July 9, 2015).

76 Won Mok Choi \& Yong Shik Lee, Facilitating Preferential Trade Agreements between Developed and Developing Countries: A Case for 'Enabling' the Enabling Clause, 21 Minn. J. InT'L L. 1-20 (2012). 


\section{Conclusion}

Currently, RTAs constitute a set of trade disciplines, many of which are complete with dispute settlement procedures, parallel to the multilateral trading system represented by the WTO. On the surface, there seems to be no apparent conflict; RTAs are authorized under the GATT/WTO disciplines and operative within the WTO system. In substance, however, exclusive trade preferences afforded by RTAs are inherently in conflict with the MFN requirement under GATT/WTO disciplines. Thus, the proliferation of RTAs has created prevalent deviations from the MFN and caused fragmentation of the trade disciplines. This development is not conducive to establishing a coherent, open, and stable multilateral trading system which will be essential to the continued expansion of world trade.

In order to remedy the current problem, the sunset policy has been proposed as a fundamental reform, which limits the duration of exclusive RTA preferences and requires the extension of the preferences to the entire WTO membership. Considering the reciprocal nature of the trade preferences, it would be unlikely for an RTA member to extend the trade preferences unilaterally to the non-members of the RTA which did not negotiate for the trade preferences. However, the suggested sunset policy may have more traction where the gains for RTA members from the proposed sunset policy would likely be larger than the loss suffered in extending the trade preferences. This reality might be possible by collective action of limiting the life of trade preferences from all RTAs. The implementation of the suggested policy would require action at the WTO level.

In the meantime, the current complexity caused by the hundreds of RTAs calls for the analysis of relevant information about RTAs presently in force. The analysis is necessary to identify potential conflicts and inconsistencies with the GATT/ WTO disciplines and those among RTAs and develop possible solutions. Some of large RTAs have been promoted for political as well as economic reasons, ${ }^{77}$ with a substantial overlap in membership. These RTAs create different regulatory approaches which lead to different outcomes in trade relations. As multiple RTAs are applied to trade between identical members, the difference in the RTAs' terms are likely to create confusion on the part of customs at borders around the world which have to process imports under the terms of multiple RTAs, as well as for those engaged in trade who have to understand those terms. The overlapping 
jurisdiction of dispute settlement forums created by multiple RTAs adds complexity to the picture, causing incoherency and confusion. A guideline for determining appropriate trade disciplines and appropriate dispute settlement procedures would be necessary to eliminate confusion and prevent destabilization of the system.

Not all deviations from the multilateral rules of trade by RTAs have a negative connotation for world trade. Some RTAs, such as the Canada - Chile Free Trade Agreement and the Australia - New Zealand Free Trade Agreement, have abolished anti-dumping measures, which do not have much economic rationale and tend to damage the trade of developing countries particularly, but are nevertheless maintained for political usage. ${ }^{78}$ Another RTA, the Singapore - Australia Free Trade Agreement, has tightened the threshold for the application of anti-dumping measures. ${ }^{79}$ Of course, the advocates of RTAs would argue that trade liberalization as a whole is a positive development for world trade.$^{80}$ However, it has been already seen that the exclusive nature of RTA preferences causes fundamental issues for the multilateral trading system.

Developing countries are particularly vulnerable in the negotiation of RTAs. As discussed, they are often under substantial pressure to join RTAs driven by developed countries for the fear of losing their export markets in the developed countries. No wonder, it is not unusual for a developing country to be presented a template drafted by a developed country and asked to agree to the presented template, without real negotiations to advance their own interests. Eventually, their negotiation positions tend to be weak. RTAs should not be used by developed countries as a device to circumvent the multilateral trading negotiations where a larger number of developing countries can advance their common interests. RTAs should also not undermine the long-term social and economic potential of developing countries by locking their current industrial structure. Just as GATT Article XVIII authorizes developing countries to deviate from their commitments to promote their industries for economic development, the same ability should be preserved for developing country members to join RTAs. Regulatory adjustment in GATT/WTO disciplines might be necessary for this purpose.

78 Supra note 63, at ch. 4.2 .

79 In the Singapore-Australia FTA, the de minimis anti-dumping margin and the negligible amount of import below which the enforcement agency cannot impose anti-dumping duties are set as $5 \%$ as opposed to $2 \%$ and $3 \%$ in the WTO Anti-Dumping Agreement, respectively. See supra note 27, at 44.

80 Supra note 13 , at 85. 